\title{
SOCIAL PLANNING AND SOCIAL POLICY
}

\section{The Development of the Regional Segment of the National System of Comprehensive Rehabilitation and Re-Socialisation of Drug Users in Certain Regions of the Russian Federation}

\author{
Dmitri D. Nevirko
}

\begin{abstract}
Dr. Sci. (Soc.), Professor, Siberian Federal University (Krasnoyarsk)
\end{abstract}
ndd-krasnoyarsk@mail.ru

\begin{abstract}
The article deals with the problem of drug abuse both at the international and Russian levels, showing its disastrous consequences on human health and disclosing the details of the drug trade. The information for the study was contributed by the administrations and governments of different regions: the Altai Krai, Primorsky Krai, Perm Krai, Stavropol Krai, Khabarovsk Krai, Krasnoyarsk Krai, Kaluga Region, Kaliningrad Region, Irkutsk Region, Rostov Region, Leningrad Region, Pskov Region, the Republic of Khakassia, Khanty-Mansi Autonomous Okrug - Yugra, and the cities of St. Petersburg and Moscow. Relying on this data, the author summarises the experience of creating regional segments in the Russian National System of comprehensive rehabilitation and re-socialization of drug users, and proposes to improve the efficiency of the process of establishing segments. He concludes that this will help to coordinate medical, psychological and social organisations; to provide cooperation between state and non-state organisations; and to implement the key mission of the Russian Federation's 2020 State Anti-Drug Policy Strategy.
\end{abstract}

Keywords: Drug addict, drug trafficking, narcotic drugs, psychotropic substances, regional segment, National system, medical rehabilitation, social rehabilitation, re-socialization, counselling centre.

DOI: $10.21684 / 2587-8484-2017-1-1-39-48$

\section{GENERAL DESCRIPTION OF THE DRUG PROBLEM \\ AT THE INTERNATIONAL LEVEL AND IN RUSSIA}

The analysis of the use of narcotic drugs, psychotropic substances, etc. for non-medical purposes is now a serious problem in the global community. The annual World Drug Report of the United Nations Office on Drugs and Crime (UNODC) indicates that in 2014 one in twenty adults, or a quarter of a billion people 15-64 y/o, took drugs at least once. The consequences of drug use in terms of health effects continue to be devastating: $1.6 \mathrm{mln}$ people live with
Citation: Nevirko D. D. 2017. "The Development of the Regional Segment of the National System of Comprehensive Rehabilitation and Re-Socialisation of Drug Users in Certain Regions of the Russian Federation". Siberian Socium, vol. 1, no 1, pp. 39-48.

DOI: $10.21684 / 2587-8484-2017-1-1-39-48$

HIV, 6 mln with hepatitis C. According to official figures, 207,400 people died as a result of drug abuse in 2014. Moreover, there were 43.5 deaths per $\mathrm{mln}$ people 15-64 y/o. The number of deaths worldwide associated with drugs remains stable. Unfortunately, only one in six drug addicts has access to treatment [15: 9-10].

The most widespread addiction in the world is cannabis: more than $160 \mathrm{mln}$ people are affected by it. $26 \mathrm{mln}$ people abuse amphetamine drugs. The volume of global production of amphetamine and methamphetamine is 300 tons/year. The number of opiate abusers is $16 \mathrm{mln}, 10 \mathrm{mln}$ of whom 
abuse heroin. In 2014, global opium production was 7,554 tons, including 657 tons of heroin. Cocaine production is estimated at 900 tons. In fact, the production and use of drugs are much higher than the official data on quantitative and qualitative indices [4].

The main factor contributing to the involvement of people in non-medical drug use is drug trafficking. It is no secret that the drug business is an extremely profitable activity. It is, in fact, a multibillion-dollar industry; its products do not even require any promotion or advertisement. The so-called western lifestyle and strict bans on the use of drugs are a perfect and free advertising campaign for drug trafficking.

Curiously enough, the ban on the sale and use of drugs makes this business very profitable. For example, the production price of $1 \mathrm{~kg}$ of opium in Afghanistan is $\$ 30-70$, i.e. 3-7 cents per gram. In the USA, $1 \mathrm{~g}$ is sold for about $\$ 40$, i.e. the sales price is approximately 550 times higher than the production cost. That is an enormous financial potential, beyond the reach of any legal business (even in favourable conditions).

According to the $\mathrm{UN}$, the annual turnover of drugs is more than $\$ 400 \mathrm{bln}$, which is comparable to Germany's annual budget.

UNODC has developed a model for a more qualified assessment of the global illegal drug trade, which shows the following: $\$ 13$ bln in production, $\$ 94$ bln in wholesale trade, and more than $\$ 400$ bln in retail. Thus, a major addition to cost takes place at the consumer level.

The proliferation of drugs is one of the threats to modern security; it causes irreparable damage to entire states, "throwing" the youngest and most dynamic groups off normal life [13]. According to the European Monitoring Centre for Drugs and Drug Addiction (EMCDDA), in the EU countries there are $70 \mathrm{mln}$ cannabis users, $12 \mathrm{mln}$ cocaine users, $9.5 \mathrm{mln}$ ecstasy users and $11 \mathrm{mln}$ amphetamine users. At least half a million EU citizens are being treated for heroin addiction; about 7,500 people die each year from an overdose [5: 13].

In more than 100 countries substitution therapy has been used for more than 30 years to fight drug addiction. The essence of this method is that an addict is switched to the use of "supportive drugs", i.e. to equivalent drugs from the same pharmacological group, which are provided by medical institutions. Despite the fact that a form of dependency is maintained, "supportive drugs" allow a person to save their life, social and legal status. Currently, more than $1 \mathrm{mln}$ drug addicts are following substitution therapy programs [18: 22]. In recent years, Iran [1:25-27] and China [6] are among the countries which have adopted this type of therapy most actively. The majority of countries of the former Soviet Union (Lithuania, Latvia, Estonia, Ukraine, Belarus, Moldova and Azerbaijan) have registered a growing number of patients receiving substitution therapy. Belarus, Georgia, Armenia and Uzbekistan have already adopted legislation allowing the implementation of such programs [19: 63-69]. However, experts do not agree on substitution therapy: there are active supporters and opponents of this method [4].

In Russia, substitution therapy is not implemented due to a legislative ban and lack of support by drug therapists and law enforcement bodies. It is obvious that this issue requires serious scientific analysis and the study of international experience, as well as the development of proposals on the possibility of its use in our country.

In 2015 about 600,000 people in Russia (vs. 656,000 in 2014, a 9.3\% reduction) were registered in drug rehabilitation institutions. However, more than $7 \mathrm{mln}$ people use drugs for non-medical purposes [9]. The high level of drug addiction is a direct threat to public safety and a major factor undermining the demographic and socio-economic potential of the country.

The importance of rehabilitation and re-socialisation of people who use narcotic drugs and psychotropic substances for non-medical purposes in Russia can be illustrated by two facts:

1) in 2015, out of 120,000 people convicted of crimes, 90,000 thousand were convicted of drug possession without the intent to sell. The latter were all drug users. Moreover, half of them were directed to places of detention, and the other half were given suspended sentences, i.e., they were released into 
society. To put a drug user into prison does not mean to protect society from criminals. On the contrary, upon their release in 6-12 months, they will usually return to drug use and illegal drug sale, this time with more eagerness and having "assimilated" criminal culture [7];

2 ) it is estimated that the laws incarcerating drug users who keep one or two doses without intent of selling cost 40 bln rubles annually. Moreover, the costs of the preliminary investigation and trial merely result in an army of drug users fully maintained by the state penitentiary system. The existing state rehabilitation programs, with budgets of just 1 bln rubles (not yet allocated), could maintain this cohort without budget funds, but in self-containment. The multiple economic benefits are obvious even to non-professionals [8].

The urgency of the issue is that at present, in Russia there is no effective national system of comprehensive rehabilitation and re-socialisation of people who use narcotic drugs and psychotropic substances for non-medical purposes (hereinafter: National System). Therefore, the country may be interested in studying the EMCDDA's experience of the drug situation. This centre collects and analyses data on drug addiction and drugs; it fosters information and comparative research methodology; the centre cooperates with EU institutions, international partners and EU countries [18]. The information collected and analysed is used to assess the situation and to develop programs of drug addiction prevention and treatment.

Despite the fact that Russia has been involved in a number of anti-drug projects in Europe and America, and has cooperated with the international organisations of the Asian region, it has taken its own measures to address the evolution of the drug situation in Russia. Unfortunately, Russia has failed to develop any effective state system to monitor the drug situation, and to rehabilitate and re-socialise drug users at a national level.

Thus, the creation of a system to monitor drug trafficking, to prevent non-medical drug use, to treat, to rehabilitate and to re-socialise drug users is an urgent task for modern Russia. To resolve this issue, the RF introduced in 2014 the state programme
"Fighting Drug Trafficking" [17]. There are few studies on drug users' rehabilitation and re-socialisation, while there is a significant amount of research in various fields of the fight against drug trafficking in Russia.

The aim of this article is to analyse the experience of creating regional segments of the National System, and to formulate proposals optimising the process. To study this problem, the author used the dialectical method, backed with historicist principles, systematisation principles, unity of theory and practice, and continuity. To collect the primary data, the author used document analysis. The empirical base of the study includes documents submitted by the administrations and local authorities of the Altai Krai, Primorsky Krai, Perm Krai, Stavropol Krai, Khaba-rovsk Krai, Krasnoyarsk Region, Kaluga Region, Kaliningrad Region, Irkutsk Region, Leningrad Region, Rostov Region, Pskov Region, the Republic of Khakassia, the Khanty-Mansi Autonomous Okrug Yugra, and the cities of St. Petersburg and Moscow [12].

\section{REGULATORY SUPPORT OF ACTIVITIES TO BUILD THE NATIONAL SYSTEM OF REGIONAL SEGMENTS}

The legal and regulatory framework of the regional segments of the RF National System is based on the federal law, which is represented by a large variety of legal documents. The state antidrug strategy has been approved until 2020 [17]. However, there is lack of coordination of certain provisions of the normative legal acts at various levels, which impedes full scale development of the procedure among departments and effective organisation of the work of the state and nongovernmental organisations (institutions) in implementing the rehabilitation and re-socialisation of drug users.

The formation of regulatory support at the RF subjects level is carried out either through the adoption of new regional laws, or amendments to existing laws, regulations, decrees and other administrative ordinance, ensuring the establishment of a regional segment of the National System. 
For example, St. Petersburg passed the law "On the Support of Socially oriented Non-profit Organisations". These organisations implement the program for drug users' identification, counselling, HIV testing, motivation for treatment and giving up atrisk behaviour, as well as their social rehabilitation and re-socialisation [19]. A number of regional regulations have been adopted in the Khanty-Mansi Autonomous Okrug, Altai Krai, Krasnoyarsk Krai, Perm Krai, Stavropol Krai, Primorye Krai, Khabarovsk Krai, Pskov region, Irkutsk region, and Kaluga region [14].

The establishment of the regional segments of the National System is a comprehensive set of legislative, organisational, administrative and financial measures taken to bring about a reduction in the problem of drug addiction among the region's population, and ultimately a fundamental solution. This system of measures is aimed at providing a gradual solution to the problems of motivation and counselling of drug users, treatment and liberation from addiction, rehabilitation and re-socialisation, as well as post-rehabilitation guidance.

The Irkutsk region has had positive experience in the establishment of motivational and counselling centres for drug users, and of rehabilitation and resocialization services. There are three such centres in the region. With the help of parents and relatives, as well as non-governmental organisations, families with drug users are identified.

In 2015, the region implemented the Healthcare Institutions Program and the Home Guard Project to develop motivational work. Within these projects, district police officers and health care workers inform drug users and their relatives about the methods of treatment for chemical addiction and the regional rehabilitation centres.

To assist people in difficult situations due to the use of drugs, the government of the region has created a 24 hour hotline at the Regional Drug Prevention Centre. The hotline offers psychological support to codependents and assists drug abuse patients' families by informing and directing them to rehabilitation centres. The officers of the centre interact with law enforcement and governmental bodies on incoming calls about possible crimes.
The Republic of Khakassia has adopted a regulation establishing a consultation and motivation station which operates under the authority of the territorial executive authorities of the municipal entities. The aim of the station is to organise, develop and extend the information system, and offer consultations to drug users in the Republic. The functions of the consultation and motivation station are:

- counselling and informing drug users and other interested parties on the provision of integrated municipal services enabling the rehabilitation and re-socialisation of drug addicts;

- establishing, maintaining and updating a data bank of registered drug users at the municipal level;

- conducting motivational work for comprehensive rehabilitation programs and re-socialisation;

- engaging in municipal and regional events on issues of cooperation in the activities of the regional segment of the National System of comprehensive rehabilitation and re-socialisation.

The St. Petersburg executive branch of the government exemplifies a positive experience in the organisation of medical rehabilitation, re-socialisation and social rehabilitation. The state institutions of social services (hereinafter: specialised services) administered by the district authorities of St. Petersburg provide drug users with social services in a semipermanent form:

- identification of families with drug users;

- motivational counselling on the issues of treatment, comprehensive rehabilitation and resocialization;

- informing addicted patients who have undergone medical rehabilitation about the possibilities to overcome the addiction with social rehabilitation techniques;

- providing certain social services to drug users who are obliged by the courts to undergo rehabilitation;

- social support and post-rehabilitation support for narcotics patients.

The specialised services play the role of supporting points where recovering addicts may seek help in their period of post-rehabilitation. The officers of the re- 
gional special services help such people to find temporary housing, to have documents reissued, to start professional training or employment; they work on the restoration of family and social relationships.

St. Petersburg is developing inter-regional cooperation with the Pskov region in the same spheres. Thus, in June 2014 a cooperation agreement was signed in the field of social rehabilitation and resocialisation of the users of narcotic drugs and psychotropic substances. An action plan was adopted for its implementation in 2016-2018.

The Cooperation Agreement comprises the following measures:

- referring narcotics patients from St. Petersburg and the Pskov region, who have undergone medical treatment and rehabilitation, to local social rehabilitation centres;

- providing St. Petersburg socially-oriented nonprofit organisations that have positive experience in social rehabilitation via rural rehabilitation centres with land and real estate belonging to the Pskov region;

- cooperation by the regions on pilot projects to establish rehabilitation centres based on agriculture and other industries;

- offering employment assistance for patients who have undertaken comprehensive rehabilitation.

In March 2015, St. Petersburg and the St. Petersburg bishopric of the Russian Orthodox Church signed a cooperation agreement. The priority areas of the cooperation are spiritual, medical and social assistance for people facing problems of alcoholism, drug addiction and HIV infection. Under this agreement, the St. Petersburg Committee on Social Policy supported a charitable foundation promoting interchurch Christian spiritual and financial aid to establish a resource centre on the basis of the Sologubovka rehabilitation centre. The resource centre provides information and assistance (methodology and staffing) to Orthodox rehabilitation centres for narcotics patients.

Krasnoyarsk Krai has organised highly specialised rehabilitative outpatient and inpatient care in Krasnoyarsk Regional Drug Dependency Clinic 1. The territory's comprehensive medical and social rehabilitation programme includes:
- diagnosis and correction of personality disorders;

— increasing the level of social adaptation of recovering addicts;

- comprehensive codependence therapy for patients' relatives;

- referral to a long-term program of medical and social rehabilitation with further regular psychotherapy for codependents, including social rehabilitation and re-socialisation in a specialised public or private centre.

In Altai Krai, the executive authorities work together with law enforcement agencies to establish a regional segment of the National System. This entails improving the regulatory framework, developing and introducing new techniques. The territory adopted measures to improve the provision of social services to drug users registered at public health institutions and to those who abandoned non-medical drug use, as well as to families in difficult situations with drug users. For these purposes, the population, drug addicts and their relatives are informed about the provision of rehabilitation and re-socialisation services in Altai Krai.

The work by non-governmental, non-profit organisations has been organised to contribute to the rehabilitation and re-socialisation of drug users. In Altai Krai there are approximately thirty registered organisations which provide social services for drug users, including five non-profit organisations operating in the field which underwent voluntary certification by the Institute for Demography, Migration and Regional Development - an autonomous, noncommercial organisation - using the criteria adopted by the State Anti-Drug Commission.

The Anti-Drug Commission of Altai Krai organised cooperation between the coordinating council, organisations dealing with the social rehabilitation and adaptation of individuals with chemical dependency, organisations affiliated to the Reintegration charity fund, and the Sodruzhestvo regional association of rehabilitation centres.

An experiment has been carried out since 2014 in Moscow concerning a certificate of social rehabilitation services for drug addicts who have undergone treatment. The experiment also includes 
former opioid replacement therapy patients from Sevastopol. To carry out the experiment, the Department of Social Protection of the population of Moscow received $100 \mathrm{mln}$ rubles in 2014 from the city's reserve fund. This figure should be considered in terms of the social rehabilitation provision cost per person ( 1,000 rubles/24 hours), the maximum duration of the rehabilitation course being 180 days. The Vozrozhdeniye ["Revival"] Moscow Social and Rehabilitation Centre for Minors is carrying out an experiment with certificates to provide drug addicts who have undergone treatment with social rehabilitation services. The centre accepts and examines applications from citizens who want to participate in the experiment. The staff of the centre inform the applicants of the available possibilities for social rehabilitation, and distribute booklets enumerating the list of documents required to obtain the certificate and lists of rehabilitation centres with their contact information (telephone number, email, etc.). The centre's staff offer visitors information materials on rehabilitation institutions (brochures, leaflets, videos) to improve their understanding of the terms of the rehabilitation process organisation.

Based on the experience of Moscow and other RF subjects, the Rostov region carried out an experiment in 2015 to provide drug-dependent citizens certified as having undergone treatment with social rehabilitation services via organisations operating in this field. The Ministry of Labour and Social Development of the region was responsible for the experiment. The regional budget allocated significant financial assets to the experiment. The subsidy rate to compensate the cost of each certificate was set within a range not exceeding 1,000 rubles/24 hours and 180,000 for the period of rehabilitation services. The certificates were granted to those applying in person and providing an extract from the their medical records (showing completed treatment for addiction), a document indicating their income, personal identification and proof of residency in the Rostov region.

Some Russian regions solve successfully the employment problems of citizens who have undergone a course of rehabilitation and re-socialisation.
In Kaluga, the Ministry of Labour and Social Protection of the Population and the Ministry of Health signed an agreement on the procedure for interaction on the issues of employment for citizens who have undergone treatment and medical rehabilitation in the Kaluga Region Drug dispensary. Under this agreement, citizens are directed to employment service agencies.

In the Pskov region, citizens who have successfully completed the rehabilitation program are assisted in employment, vocational training and additional professional education to enhance their competitiveness on the labour market. The Pskov Region State Committee on Labour and Employment and the Ruchey ["Brook"] rehabilitation centre signed the agreement for cooperation and coordination of actions promoting the employment of people who have received rehabilitation services in the centre.

Some RF regions systematically train specialists in the field of rehabilitation and re-socialisation of drug addicts. In 2015, the Altai State Pedagogical University introduced a course Organisation of the Social Rehabilitation and Re-Socialisation of Members of the Psychoactive Substance-User Risk Group. The aim of the four-month course is to develop the professional skills of consultants in the field of psycho-social work with vulnerable groups of people. Basic medical training in the field of drug pathology, complications and the consequences of drug use is coupled with an introduction to the regulatory framework of rehabilitation aid organisation. This professional development programme for consultants and heads of non-governmental rehabilitation centres was developed by leading university educators, including psychologists and lecturers from the Institute of Supplementary Education, the Institute of Psychology and Pedagogy, the Department of Medical Knowledge and Life Safety, as well as drug therapists. Upon the course's completion, students receive a government-issued certificate of advanced training in the field of rehabilitation and re-socialisation of drug users. Other regions of Russia have shown interest in this course.

In St. Petersburg, the Family (the city's information and methodical centre) develops curricula and training in social rehabilitation techniques and pro- 
vides social support for people with dependent and codependent behaviour. Also, scientific, methodological and informational support has been developed by the executive authorities of St. Petersburg and their subordinate organisations for social rehabilitation and re-socialisation of people with dependent and codependent behaviour.

The Development of Health Care state program of the Perm region provides annual training in rehabilitation techniques in the leading research centres of Russia. To develop this inter-agency cooperation, the region organises workshops, thematic round tables and informational seminars on rehabilitation questions, as well as an annual forum Who Will Help Alcoholics and Drug Addicts? Issues of Rehabilitation.

Overall, we can summarise the following major activities that form the model of regional segments in certain RF subjects:

- the creation of a regional regulatory and legal framework that allows clear definition of the work of public authorities, local governments, and the institutions and organisations operating in the field of the rehabilitation and re-socialisation of drug users;

- the allocation of budget funds of RF subjects to organise work in the field of rehabilitation and re-socialisation;

- the organisation of multi-level systems of work with drug users, including detection, diagnosis, treatment, medical rehabilitation, social rehabilitation, re-socialisation and post-rehabilitation support.

In our view, the perspectives for developing the regional segment of the National System are:

- event planning to create motivational centres and counselling centres to inform drug users about services of rehabilitation and re-socialisation, aand to work with codependents;

- the introduction of 24-hour hotlines to allow drug addicts and codependents to seek consultactions, complementing the activities of motivational centres;

- the organisation of post-rehabilitation support for citizens who have previously used drugs and psychotropic substances for non-medical purposes;

- the implementation of measures on the use of registered certificates for the payment of social rehabilitation services for drug users who have undergone treatment and rehabilitation;

- the development of criteria (standards) for the provision of services for the rehabilitation and re-socialisation of former narcotic drug or psychotropic substance users;

- certification for the organisations that provide services of rehabilitation and re-socialisation of drug users, and cooperation with such organisations, built on the principles of public-private partnership, increasing the volume, improving the quality of services and creating additional conditions conducive to stable, positive motivation for treatment and rehabilitation.

In order to improve the National System, we suggest the following measures at federal and regional levels:

- amending the RF anti-drug law to provide a complete system of legal regulation in the field of rehabilitation and re-socialisation, including at municipal level;

- defining the powers and responsibilities of all government levels within the framework created by the National System, and a uniform procedure to implement the activities carried out by the regions;

- determining the federal executive body authorised to solve problems in the field of the rehabilitation and re-socialisation of individuals who have undergone treatment for alcohol and drug addiction;

- developing the regulations that define the minimum requirements for non-governmental organisations providing services for social rehabilitation and re-socialisation of drug users (these regulations may be updated, if necessary, by the RF subjects);

- developing uniform criteria for evaluating the effectiveness of rehabilitation programs;

- creating a single federal register of medical, social and non-governmental organisations providing rehabilitation services to drug users in the RF; 
- creating a single interagency electronic database of drug users undergoing comprehensive rehabilitation;

- distinct powers for the healthcare system, social protection system and employment services in the field of the rehabilitation and re-socialisation of drug addicts;

- determining the rules of interaction among the organisations that provide healthcare for narcotics users and the organisations working for their rehabilitation and re-socialisation;

- developing a model program for the social rehabilitation of drug addicts, defining the conceptual conditions of rehabilitation assistance;

- introducing Internet hotlines through the official portals of the regional administrations and institutions providing medical assistance to drug addicts; placing banners with information about online dialogue with specialists (drug therapists, psychiatrists, social psychologists, etc.);

- strengthening compulsory treatment of drug addicts evading voluntary treatment and violating public order regularly;

- developing a model program of rehabilitation for adolescents (12-17 y/o; according to the monitoring data, this age range is at risk) which determines the main directions in rehabilitation and re-socialisation of juvenile drug users;

- developing additional measures to support nongovernmental rehabilitation centres through subsidies, benefits or property (land), providing advice and information support;

- granting facilities and land plots (as land tenure) to rehabilitation centres, encouraging the rehabilitation and re-socialisation of drug users through activities including crop production and livestock breeding;

- arranging monitoring of rehabilitation centres' activities in order to prevent violations of drug addicts' civil rights;
- increasing the availability and transparency of the system of voluntary certification for rehabilitation centres;

- introducing rehabilitation certificates in a federal-approved format valid across the RF and making provisions for their conditions of issue and financing;

- financing education (vocational training) for the representatives of non-governmental rehabilitation centres, as well as the agencies and departments involved, from the federal budget;

- developing a regional legal framework for the provision of tax incentives to companies and organisations which provide logistical support to non-profit rehabilitation organisations and employ rehabilitants;

- developing a support program for entrepreneurs providing employment to addicted patients who have successfully completed rehabilitation and are currently in remission;

- impeding the activities of destructive religious organisations through qualification and universal control by public authorities over the activities of religious organisations providing services for the rehabilitation and re-socialisation of drug users;

- using existing positive international experience in drug demand reduction [2], the implementation of replacement (methadone) therapy [21] and the creation of a sustainable system of rehabilitation and re-socialisation of drug users [3].

In conclusion, it should be emphasised that the establishment of the regional segments of the National System will coordinate the work of medical, psychological and social structures. It will ensure a network of partners and the interaction of state and non-governmental organisations working together towards an effective rehabilitation environment and the ability to change the lives of rehabilitants. All these measures will bring about the key objective of The Russian Federation's 2020 State Anti-Drug Policy Strategy. 


\section{REFERENCES}

1. Ahmadi J. 2002. "Buprenorphine Maintenance Treatment for Iranian Patients with Opioid Dependency". Addictive Disorders \& Their Treatment, vol. 1, pp. 25-27. DOI: 10.1097/00132576-200205000-00005

2. Dosage Trends in Methadone Maintenance Treatment Programs: Significant Improvement, but Still Below Evidence-Based Standards: Research Report, August 19, 2014. Addiction Treatment Forum. Accessed 5 September 2016. http://atforum.com/2014/08/dosage-trends-mmt-programs-significant-improvement

3. EMCDDA. 2002. Annual Report on the State of the Drugs Problem in the European Union and Norway. Accessed 5 September 2016. www.annualreport.emcdda.eu.int

4. EMCDDA. 2003. Legal Aspects of Substitution Treatment. An Insight into Nine EU Countries.

5. EMCDDA. 2008. Annual Report: The State of the Drugs Problem in Europe, p. 13. Lisbon.

6. Hartelius J. 2008. Narcoterrorism. Policy Paper, no 3. Accessed 5 September 2016. https://www.ciaonet.org/attachments/823/uploads

7. Ivanov V. P. 2016. "Aktualnye problemy realizacii Strategii gosudarstvennoy antinarkoticheskoy politiki" [Urgent Problems in the Implementation of State Anti-Drug Policy]. The Scientific and Practical Conference (March 3, 2016, Kutafin Moscow State University). Accessed on 5 September 2016. http:/www.fskn.gov.ru/in-cludes/periodics/speeches_fskn/2016/0303/111542908 / detail.shtml

8. Ivanov V. P. 2016. “Ob itogakh operativno-sluzhebnoy deyatelnosti Federalnoy sluzhby Rossiyskoy Federacii po kontrolyu za oborotom narkotikov v 2015 godu i zadachah na 2016 god” [The Results of the Activity of the Federal Service of the Russian Federation in the Prevention of Drug Trafficking in 2015 and Its Objectives for 2016]. Report presented at the meeting of the Federal Drug control Service of Russia (18 February 2016, Moscow). Accessed 5 September. 2016 http://www.fskn.gov.ru/includes/periodics/speeches_last/2016/0218/121242644/detail.shtml

9. Ivanov V. P. 2016. Intervyu predsedatelya Gosudarstvennogo antinarkoticheskogo komiteta direktora FSKN Rossii V. P. Ivanova Informacionnomu agentstvu Rossii TASS 11 marta 2016 g. [Interview with V. P. Ivanov, Chairman of the State Anti-drug Committee, Director of the Federal Drug Control Service with Russian News Agency TASS on 11 March 2016]. Accessed 5 September 2016. http://www.fskn.gov.ru/includes/periodics/speeches_fskn/2016/0311/093143099/detail.shtml

10. Mendelevich V. D. 2006. "Zamestitelnaya terapiya narkomanii - novaya problema biomedicinskoy etiki i medicinskogo prava" [Replacement Drug Therapy is a New Problem in Biomedical Ethics and Medical Law]. Nezavisimyy psihiatricheskiy zhurnal, no 1, pp. 63-69. Accessed 5 September 2006. http://www.npar.ru/journal/2006/1/therapy/htm

11. National Drugs Information System. Accessed 5 September 2016. http:/www.emcdda.europa.eu/ attachements.cfm/att_149514_RU_ReitoxRuss; http://nijd.uredzadroge.hr/index.php/en/informationsystem

12. Nevirko D. D., Fedorova E. A. 2016. Polozhitelnyy opyt raboty po organizacii regionalnogo segmenta Nacionalnoy sistemy kompleksnoy reabilitacii i resocializacii lic, potreblyayuschih narkoticheskie sredstva i psihotropnye veschestva v neme-dicinskih celyah, v otdelnyh subektah Rossiyskoy Federacii: analiticheskiy obzor [The Positive Experience of the Organisation of a Regional Segment of the National System of Comprehensive Rehabilitation and Re-Socialization of Narcotic Drugs Users and Psychotropic Substances for Non-Medical Purposes in Certain Regions of the Russian Federation: Analytical Review]. Krasnoyarsk: SibYuI FSKN Rossii.

13. Potyomkina A. Yu. 2009. “Antinarkoticheskaya politika Evropeyskogo Soyuza” [The European Union's Anti-Drug Policy]. Vsya Evropa, no 5(33). Accessed 5 September 2016. http://alleuropalux.org/?p=2229

14. Pskov Region Law of 6 June 2014 no 1401-OZ “O vnesenii izmeneniy v Zakon Pskovskoy oblasti 'O poryadke opredeleniya razmera arendnoy platy, poryadke, usloviyah i srokah ee vneseniya za ispolzovanie zemelnyh uchastkov, nahodyaschihsya v sobstvennosti Pskovskoy oblasti, i zemelnyh uchastkov, gosudarstvennaya sobstvennost na kotorye ne razgranichena, na territorii Pskovskoy oblasti"” [Amendments to the Law of the Pskov Region "On the Procedure for Determining Rent and Its Terms and Conditions for the Use of Land Slots Owned by the Pskov Region and Land Plots Whose State Ownership 
Is Not Delimited on the Territory of the Pskov Region"]. Accessed 5 September 2016. http://docs.cntd.ru/document/924011852

15. Report of the International Committee for Drug Control for 2015 on the implementation of Art. 12 United Nations Convention against Illicit Traffic in Narcotic Drugs and Psychotropic Substances of 1988. Accessed 5 September 2016. http://www.unis.unvienna.org/unis/protected/2016/AR_press_kit_R.pdf17

16. RF Government Decree of 15 April 2014 no 299 “Ob utverzhdenii gosudarstvennoy programmy Rossiyskoy Federacii 'Protivodeystvie nezakonnomu oborotu narkotikov"” [On the Approval of the Russian Federation State Program Entitled Combating Drug Trafficking]. Accessed 5 September 2016. http://www.consultant.ru/document/cons_doc_LAW_162168

17. RF President Decree of 9 June 2010 no 690 “Ob utverzhdenii Strategii gosudarstvennoy antinarkoticheskoy politiki Rossiyskoy Federatsii do 2020 goda" [On the Approval of the Russian Federation's 2020 State Anti-Drug Policy Strategy]. Rossiyskaya gazeta, no 128. Accessed 5 September 16. http://www.gov.karelia.ru/Legislation/lawbase.html?lid=7911

18. Robertson R., Burrowes D. 2010. "Methadone: To Use or Not To Use". The Guardian. Accessed 5 September 2016. https://www.theguardian.com/society/joepublic/2010/apr/20/methadone-drugs-policy

19. St. Petersburg Act of 11 April 2011 no 153-41 "O podderzhke socialno orientirovannyh nekommercheskih organizaciy v Sankt-Peterburge (s izmeneniyami na 21 iyunya 2016 goda)" [On the Support of Socially Oriented Non-Profit Organisations in St. Petersburg (as of 21 June 2016):]. Sankt-Peterburgskie vedomosti, no 71; Vestnik Zakonodatelnogo sobraniya Sankt-Peterburga, no 15.

20. The World Drug Report 2016, pp. 9-10. Accessed 5 September 2016. https://www.unodc.org/doc/wdr2016/WORLD_DRUG_REPORT_2016_web.pdf

21. Wikipedia. "Drug Rehabilitation”. Accessed 5 September 2016. https://en.wikipedia.org/wiki/Drug_rehabilitation 